\title{
Ethical Issues In Accounting: A Teaching Guide
}

Amy L. Doolan, DBA, Mercyhurst University, USA

\begin{abstract}
Theodore Roosevelt said, "To educate a person in mind and not in morals is to educate a menace to society." With this quote in mind, this paper describes three ethical issues in the discipline area of accounting. The format of the paper is to first provide background information on the ethical question or scenario then to provide a pedagogical approach for presenting the issue to undergraduate accounting students. Finally, a teaching guide for the professor to utilize in lecturing the topic, a sample assignment related to the topic, and ways to assess the outcomes of the assignment is provided.

Relevant literature on the topics chosen is provided in summary in the background section of each issue. The pedagogical exercises are designed to incorporate elements of deontological, utilitarianism, and virtue ethical systems. Additionally, students are asked to consider the Christian worldview in their responses to the ethical issue and also discuss how Scripture impacts their decisions.
\end{abstract}

Keywords: Accounting Ethics; Teaching Accounting

Ethical Issue \#1: Should accounting professionals be required to take a formal ethics course (in a college/university setting) before being admitted to the profession?

\section{BACKGROUND}

$\mathscr{I}$ $\mathrm{n}$ a recent article published in the January 2007 issue of The CPA Journal, authors Bean and Bernardi argue that the accounting profession has the right, and perhaps even the obligation, to require accounting students to complete an ethics course prior to becoming a member of the profession. In a business environment that has become increasingly complex with its many shades of gray, they argue that accounting professionals need more guidance than ever before in addressing events and transactions while fulfilling their duty to society. As such, the authors conclude that the academic world cannot turn its back on the need for accounting ethics courses.

From a regulation standpoint, the move by the National Association of State Boards of Accountancy (NASBA) initiating proposed revisions to the Uniform Accountancy Act (UAA) sparked a great deal of debate. Specifically, the NASBA's exposure draft addressed the need, among other things, to (1) clarify the manner in which Boards determine applicant ineligibility due to lack of good moral character, and (2) add an ethics continuing professional education (CPE) requirement for the renewal of certification/registration (NASBA, 2006). The NASBA left the exposure draft open for public comment through April 30, 2007 and encouraged both practitioners and academics to weigh in on these proposals. This regulatory move seems to support the argument from Bean and Bernardi (2007) that ethics is of primary importance in the accounting profession and one the academic community needs to address, beginning with undergraduate accounting curriculums.

The Association for the Advancement of Collegiate Schools of Business (AACSB) has also commented on the issue of ethics education. The AACSB's Ethics Task Force issued a publication titled Ethics Education in Business Schools, and while the task force did not prescribe a particular course or recommend a specific curriculum requirement, it advocates member schools and faculties to "....renew and revitalize their commitment to ethical 
responsibility at both the individual and organizational levels", while also encouraging that schools "...strengthen ethics components" in the curriculum (AACSB, 2004, p.14).

Would mandating students complete an ethics course influence their behavior and encourage them to act more ethically as future accounting professionals? The literature is scattered with mixed messages on whether such training provides these intended results. In the absence of significant proof that requiring ethics in the accounting curriculum/ education would result in "more ethical" accounting professionals, what ought we to do? Is the probability that ethical choices will be made more often if students are exposed to increasing ethical education high enough to warrant a mandate that ethics education be required of all accounting students?

What do accounting students think of the debate that is brewing over whether or not ethics can and should be taught at the college level? According to Bean and Bernardi (2006), this is the question that gets at the heart of the debate, but one that the profession itself has been seemingly unwilling to ask. Bean and Bernardi claim "[t]he accounting profession and its regulators have overlooked their responsibility to solicit students' views on requiring a separate accounting ethics course and business ethics course, as well as the importance of ethics within the accounting curriculum" (p. 56). Is the profession thereby missing the boat by overlooking the viewpoints of potentially the primary stakeholders in this debate - the students?

\section{THE OPPOSING VIEWPOINTS EMERGE}

In an advanced accounting course in a private University in New York state, 30 students were required to take a position on the NASBA proposal that students take additional accounting ethics courses prior to sitting for the CPA exam. Students were also asked to comment on whether or not ethics can be taught in the classroom (Bean and Bernardi, 2006).

Two basic opposing viewpoints were uncovered as a result of this investigation into students' thoughts regarding ethics: (1) Ethics can and should be taught in the classroom and (2) Ethics cannot be taught in the classroom at the college level since at this stage someone is either ethical or they are not.

"An interesting debate exists within the academic community about whether our universities can or should influence the ethical behavior of their students" (Copeland, Jr., 2005, p. 40). Some studies suggest that students' professional attitudes and thus their likelihood of engaging in ethically acceptable activities, is not influenced by their study of ethics (Clikeman, 2003). Those arguing that ethics cannot and should not be taught in the college setting argue that moral foundations are formed early on in life and cannot be changed or influenced by the time students are of college age. This is found to be especially true when considering the average age of MBA students ranges from 28 to 30 years old (Copeland, Jr., 2005). Others suggest that under capitalism, with profits and greed as significant motivators, ethics are part of one's personality or culture and cannot be taught (Rothenberg, 2003). Still others argue that the Bible would support the argument that ethics cannot be taught as or legislated (Howard, 2007). Jeremiah 17: 9-10 reminds us that "the heart is deceitful above all things and desperately sick". "Therefore, no amount of ethics training will preclude illegal and unethical behavior" (Howard, 2007, p.15). It seems additional support for the argument not to teach ethics could easily rest upon the fact that just because the accounting profession has a well-developed and well-recognized ethical code of conduct does not mean that all members of the profession will act ethically.

Is the real debate here about the motivation to be ethical? Can students be motivated to act ethically as future accounting professionals? Maybe an equally important question to consider is can people change? If the literature suggests that students reach a certain age and form moral foundations that cannot be influenced or changed and therefore teaching ethics to them is unfounded, what does that mean for God's willingness to work change in someone's life? Doesn't God want to change us from people who live unto ourselves to people who live in the likeness of Him? Peter writes of positive, personal changes we expect as our own hopes and dreams begin to line up with those God has planned for us, stating " $[t]$ hrough these he has given us his very great and precious promises, so that through them you may participate in the divine nature, having escaped the corruption in the world caused by evil desires." (2 Peter 3:4) 


\section{STUDENT ASSIGNMENT}

Similar to the exercise at the NY state College mentioned in the background, your role is to take a position on the ability of ethical behavior to be taught to undergraduate students in a classroom setting. There are two obvious positions: ethics can and should be taught in the classroom OR ethics cannot be taught to undergraduate accounting students; someone is either ethical or they are not. After stating your chosen position, you should adequately defend that position in a written paper (double spaced, 1" margins, Times New Roman font, 12 point) that is no less than 5 pages.

Prior to developing your position paper you should have read thoroughly the Bean and Bernardi (2006) article provided to you. You may choose to read related literature on the topic of accounting ethics education in the development of your response. You may want to consider the impact/influence/significance (or non significance) of professional codes of conduct and government legislation upon the ethical behavior of businesspersons around the world today since this ethical question greatly mirrors the one regarding the ability (or inability) of regulators/standard setting bodies to "legislate" ethical behavior via either professional codes of conduct and/or actual legislation.

When writing your position paper you need to also reflect upon how your answer to this question has changed or been influenced by the accounting curriculum here at the College. For example, if you were asked this question as a freshman or sophomore who had taken only one or two accounting courses, how would your response differ than your response now, as a senior who has fulfilled all of the accounting core requirements?

Paramount in your paper is the consideration of your own religious beliefs about this issue. Please express how they influence your position and how you might explain to someone on the other side of the issue why/how you arrived at your position. Additionally, you should include some reference to specific ethical theories (utilitarianism, Kantian ethics, virtue ethics) that support your argument for or against the teaching of ethics at an undergraduate level.

\section{GRADING CRITERIA}

This assignment will be graded based upon the following criteria:

1. Clear articulation of a position either in favor or against the idea of mandated ethics courses for accounting students at the undergraduate level based primarily upon whether or not you believe that ethics can be taught and learned in a college setting.

2. Specific reference to your own spiritual/religious beliefs that inform/influence this position. Ethical principles from your chosen ethical system should also be discussed (in other words, you cannot just say "I believe the answer is yes/no"; you need to support your answer with the ethical and spiritual principles that guide your response.)

3. A defendable position and articulation of why the position taken is superior to the opposing viewpoint.

4. Discussion of how 4 years of accounting coursework has influenced the position taken.

5. Grammar, punctuation, readability and the following of specific directions regarding format as provided by the Professor.

\section{TEACHING GUIDE}

This exercise would be administered to students in the 400-level advanced accounting course.

There are multiple reasons for the selection of this assignment. First, this issue is important to the profession and therefore worthy of investigation by the academic community. Secondarily, from a student perspective, with the assignment being given during what is likely the last accounting course in the curriculum, it will allow students to explore their own thoughts about ethics in general and more specifically perhaps how their concept of ethics has changed as a result of progressing through the College's accounting curriculum and/or being an accounting major. It would be ideal if students made reference to a specific "ethical dilemma in accounting" that 
they discussed, debated, or otherwise engaged in during a prior accounting course at the College. Discussion of any "real life" experiences that students have encountered up to this point which may influence their perspectives ought to be encouraged.

The discussion outcomes of this assignment are also multiple in nature. Primarily, discussion might focus upon what students perceive to be their own internal/external ethical referents, and what it means to be an accountant in whatever roles they choose to pursue upon completion of the degree (i.e.: public accountant/CPA, cost accountant, not-for-profit/government accountant, etc.). I believe this discussion will lead into an opportunity for students to examine whether or not their own personal/moral/ethical value system is truly in sync with what is expected of them in their careers as accounting professionals. Additionally, because the students will have diverse spiritual/religious backgrounds and beliefs, it will be desirable for students to hear and learn about how different denominations influence an accounting ethics scenario.

It is worth pointing out to the students that on the face, it appears that this question can be answered relatively simply as either yes or no. However, it is worth asking the students to consider the deeper questions at the root of an issue such as this one. Personally, one underlying question appears to be: do we need proof of something in order to deem it valuable/worthy? Do we need proof that the outcomes of ethics education (producing "more ethical" accounting professionals in the future) exists before we support the whole notion of ethics in accounting education? From a Christian perspective, this initiates discussion on topics of faith and trust. Faith is being sure of what we hope for and certain of what we do not see (Hebrews 11:1) and while images appeal to our flesh, as Christians, we are called to walk by faith and not by sight (2 Corinthians 5:17). It would be ideal if students made reference to this or similar Scripture if arguing that ethics can and should be taught in the classroom and that we need not wait to see if doing so can bring about more ethical future accountants.

I would expect a balanced argument between psychological egoism and virtue ethics to be reflected in the students' responses. Psychological egoism is what I believe to be behind the reference that people are at heart selfish and the heart is deceitfully sinful. This is the view that everyone is always going to be motivated to act in his/her own self-interest, a tenant of psychological egoism (Beauchamp and Bowie, 2001). When I made reference to "motivation" to act ethically within the opposing viewpoints discussion, I was eluding to the principles of virtue ethics that descend from classical Plato and Aristotle traditions. What would students consider to be the appropriate virtues of professional accountants? Virtues that have received consideration as appropriate for managers engaged in business activity include integrity, courage, and compassion (Beauchamp and Bowie, 2001). This is interesting since CEO's for instance are sometimes regarded as possessing quite different character traits. A discussion of the characteristics of holiness, justice, and love is worth incorporating into the lecture on virtues as these are the complete characteristics of business ethics (Stevens and Banks, 2005). "The ultimate goal is to produce practitioners who imitate God's holy, just, loving character in the marketplace. This is the true character of biblical business ethics" (Stevens and Banks, 2005, p.33).

This is also an important topic for educators as I believe it speaks to the ever important concept of character. Within the parameters of virtue ethics it is presumed that a person who simply follows the rules of obligation without exhibiting any special moral character may not be trustworthy. On the contrary, a morally good person who also upholds the right desires and motivations is more likely to understand what should be done and more likely to perform right actions and act on moral ideals. In this respect, it is not the rule follower, but instead the person disposed by character to be upheld as a moral model. At the same time, it can be argued from the opposite side of the spectrum that imparting knowledge is not the same as inspiring or encouraging behavior or character; thus, teaching ethics might have little impact upon the behavior of future accountants (Goldsmith, 2005). 
Ethical Issue \#2: Should the audit profession have more rigid rules to guide audit practices than the generally accepted auditing standards/PCAOB auditing standards, or does tightening these standards impede upon the auditor's professional judgment?

\section{BACKGROUND}

The American Institute of Certified Public Accountants (AICPA) developed a set of guidelines to aid auditors in fulfilling their professional responsibilities in the audits of historical financial statements. These guidelines, referred to as the 10 generally accepted auditing standards $(\mathrm{GAAS})^{1}$ fall into three categories: general standards, standards of field work, and reporting standards. Together, these standards "....are not sufficiently specific to provide any meaningful guide to practitioners, but they do represent a framework upon which the AICPA can provide interpretations" (Arens, Elder, and Beasley, 2008, p. 33).

GAAS (along with the Auditing Standards Board's Statements on Auditing Standards) are regarded as authoritative literature and under the AICPA's Code of Professional Conduct every member of the AICPA who performs audits of historical financial statements is required to follow them. Still, despite this authoritative status, the guidelines provide no specific requirements for auditors' decisions like determining sample size, selecting sample items from a population, or evaluating the results of evidence gathered. Further, GAAS, as simply minimum standards of performance, do not always need to be followed. Provisions exist for the auditor to follow an alternative action if he/she believes that the requirement of the standard is impractical or impossible to perform (Arens et al. 2008).

As Ricchiute (2006) points out, standards like the GAAS are not step-by-step procedures for conducting an audit, nor are they intended to be. "Standards are the guidelines from which procedures are derived, the measures of quality against which completed engagements are judged" (p.36). In audit, decisions about sampling and evidence gathering and materiality in evidence evaluation are regarded as estimates that require a high-level of subjective, professional judgment on the part of the auditor (Arens et al. 2008).

Constitutional law is based upon interpretations of a single document, the United States Constitution. In some respect, audit services work the same way. GAAS are to audit services what the Constitution is to constitutional law. The standards are designed to provide guidance over questions that arise regarding issues like training, independence, due care, supervision of an audit, materiality, and risk. The nature of the standards has been a debate for many years. As far back as the 1970's GAAS were criticized often by practitioners who found them to be insufficiently specific (Ricchiute, 2006).

\section{THE OPPOSING VIEWPOINTS EMERGE}

Are practitioners justified in their argument that the GAAS should provide more clearly defined guidelines for the important audit decisions that are left up to the individual auditor's professional judgment today (i.e. sufficiency of evidence, application of materiality, sampling procedures, etc.)? Would making the standards more specific eliminate some of the difficult audit decisions today's auditors face and thus provide a line of defense for a CPA firm who is charged with conducting an inadequate audit (Arens et al. 2008)?

What about the opposing side? Would tightening the specificity of the GAAS impede upon the professional judgment of the auditor? Does being a CPA and an auditor mean that you have "earned" the right to exercise your professional judgment in the above-mentioned situations during an audit of historical financial statements? Additionally, would making these standards more specific turn an audit engagement into merely a mechanical process, one that requires only the ability to "follow rules" and requires less critical thinking and exercise of judgment?

\footnotetext{
${ }^{1}$ After the 2002 passage of the Sarbanes Oxley (SOX) legislation, the Public Company Accounting Oversight Board (PCAOB) was given authority to set auditing standards for public company audits. Therefore, for public companies these standards are now referred to as the PCAOB auditing standards. GAAS continues to be used for audits of private companies.
} 
As with most ethical dilemmas, the person making the decision often must consider elements beyond the legality of the issue. Here, it's not "illegal" for the standards to be left as they are. So, what are the implications of changing them? Under the principles of utilitarianism, one would commit to the maximization of good and the minimization of evil (Beauchamp and Bowie, 2001). Businesses and government agencies that employ this ethical approach also adopt specific tools like cost-benefit analysis and risk assessment when analyzing a dilemma. Here, the cost-benefit of changing these standards seems like a likely area of investigation. This type of analysis is employed frequently in ethical dilemmas in accounting. The difficulty here is that while the costs of tightening the standards are likely to be easily calculated, the benefits are without a doubt more difficult to quantify. Quantifying the benefits is often a problem when the cost-benefit analysis technique is employed during analysis of an accounting dilemma (Kieso, Weygandt, and Warfield, 2007).

Given the two opposing viewpoints and the potential impact on various parties, which party ought we to consider paramount when making the call on the specificity of the standards? Is the greatest impact the one upon the auditor, the user of the financial statement information, the standard setters, or the profession in general? Ought we to apply strict utilitarian principles and work to find the greatest good for the greatest number? How do we measure whether such "good" has been achieved?

Maybe a more important question to ask is: Does it matter whether the rules are "specific" or not? Does the flexibility in the interpretation leave room for grey areas that could be avoided if the standards were more specific, or does the call for specificity just represent the practitioners' desire to have something to cover them in the event of scrutiny?

\section{CLASS DISCUSSION AND STUDENT ASSIGNMENTS}

I would incorporate this exercise and subsequent writing assignment in a 400-level auditing course. I would begin with a lecture that incorporates the following:

Consider the word interpretation. Barron's Accounting Dictionary offers this definition:

Opinion regarding a set of facts. A degree of subjectivity is involved on the part of the individual, based on his or her experience, personality, and biases. For example, after performing a detailed analysis of the financial statements of a company, two financial analysts may differ in their perceptions of what the market price of the company's stock should be.

Within this definition we see the words subjectivity, experience, personality, and biases. Interpretation is at the heart of this accounting dilemma. Questions include but are not limited to: Should we leave the GAAS as is and therefore rely on the auditors' interpretation of those standards, influenced by his/her personality, experience, professional judgment and biases? Do we want/need more stringent rules to follow, especially in the light of recent accounting scandals that also involved audit firms?

As you consider this dilemma, imagine your first day on the job as an auditor, heading off to your very first audit engagement. Would you be comfortable making decisions about sample size, materiality, and audit risk when armed only with the vague 10 GAAS as your guide? If not, would you be willing to forgo some of your professional judgment in lieu of more stringent standards? Would you feel differently if this were your $5^{\text {th }}$ year on the job? Would you then want to exercise more professional judgment and be more likely to resent the impediment of the stringent standards on your ability to exercise that judgment?

Have you ever come upon a biblical story or passage that you consider bothersome with regard to interpretation? Why did (does) it perplex you? What about it seems conflicting or ambiguous? Do you often wish that you could get clarification on it? Have you ever had a conversation with another person who interprets that passage or story differently? How do you resolve who is "right", or do you agree that you may both be right?

After having a lecture and class discussion on these questions I think the best way to accomplish this exercise is in a debate type fashion. I would ask students to volunteer a verse, passage, or story from the Bible that 
they find to be ambiguous or subject to interpretation. After listing a few of these I would assign students a partner and ask that they prepare to debate the interpretation from two different interpretations/standpoints, relating the passage if possible to business/accounting.

\section{WRITING ASSIGNMENT}

Separately, I would ask the students to consider the question about whether tightening the wording and specificity of the GAAS is warranted. I would ask them to apply appropriate ethical theories to support their position while also considering their religious beliefs articulated in the debate.

To engage students in thought about the writing assignment, I would ask them to reflect upon the 10 Commandments. Are these "specific" enough? Is there room for "interpretation" of these Commandments; in other words, do students read these Commandments and follow them with statements like "that's not REALLY what God meant, or that's not REALLY what the Scripture implies".

Additionally, I would ask that students consider in their writing assignment the fact that within this particular accounting dilemma there is extreme possibility for a self-serving approach. In other words, practitioners who argue in favor of tightening the standards may merely be looking for a way to cover themselves from possible litigation arising from accusation of conducting an improper audit. On the flip side, those arguing against adjusting the specificity of the standards object highly to the way doing so would impede upon their ability to exercise their own professional judgment. How would someone on either side of this argument reconcile their own self-serving viewpoint with the Biblical inference that God is in control? Students need to explain thoroughly their reasons for adjusting/not adjusting the standards while also reconciling their position such that it does not fulfill some selfserving role.

\section{TEACHING GUIDE}

The debate session is designed to allow students to explore their own ethical and biblical reference points and incorporate them into a discussion about business. The writing assignment is designed to allow students to see that in accounting, and in ethics, there is frequently not one "right" answer. Frequently in the profession and with ethical dilemmas, we arrive at different definitions of "right".

The students' responses to the question regarding the adjustment of the GAAS cannot be marked as right or wrong; instead, students must work to understand within themselves why they feel what they feel. I hope this will allow them to appreciate their own ethical and biblical perspectives more deeply while also allowing them opportunity to delve into the intricate area of accounting regulation, which is not as clear-cut as students may assume. Additionally, by asking them to consider how they would feel about this as a brand-new auditor versus someone who has been an auditor for several years will hopefully allow students to see that you cannot have it all. It is impossible to set a standard one day and then attempt to circumvent it five years down the road when you feel you have "more experience"....indeed, it is this sort of behavior that leads to so many extreme accounting infractions like those that have tarnished the profession in recent years.

How students work with the "interpretation" /debate exercise should also produce some valuable thinking and reflection. With my pointing students to the 10 Commandments specifically as an example, some of their reflections might include thoughts such as:

- How do we interpret/translate certain Commandments - for example, does the sixth Commandment mean "you shall not kill" or "you shall not commit murder"?

- Consequentially, there are differences between the Decalogue within the Old Testament. For example, the reference to "remembering" the Sabbath in Exodus is related to creation of the seventh day as the Sabbath; but in Deuteronomy, we speak of "observing" the Sabbath as a reminder to Israel that they were slaves in Egypt.

- Even within Christianity, the Commandments are divided up differently. Roman Catholics see the Commandment regarding images and idols as one with the prohibition of other Gods while the Orthodox traditions view this as a separate, distinct Commandment. 
Once students see that within the 10 Commandments alone we are able to come up with these differences in "interpretation", it ought to lead us easily back to the discussion of the standards and the pros/cons of having 'loose' guidelines that do not impair one's ability to express professional judgment versus having more 'strict' guidelines that do not lend themselves to highly subjective interpretation.

This topic might also spark discussion about the need for power in the profession. Those who feel that they have somehow earned the right to exercise their own professional judgment because of their title (CPA) or position with the firm need to consider the ease with which power can lead to corruption. While power in the workplace may be granted us because of our competence, skill, and fitness for the assigned tasks, our motivations as Christians is based not on the potential for rewards from our employers but on our desire to please God (Stevens and Banks, 2005). "And whatsoever ye do in word or deed, [do] all in the name of the Lord Jesus, giving thanks to God and the Father by him" (Col. 3:17).

Additional Teaching Note: To prepare the students for the in-class debates, during the course of the term the students can work through ethical questions posted to the Discussion Board on the College's blackboard system. The professor will post questions from the ethical problems in the textbook and ask students to respond to 1 of the questions posted. Then, students would also be asked to respond to the response of one other student who would become his/her peer for those sessions. This practice might lead to the formation of a "relationship" between the two students for purposes of later becoming peers for the in-class debate exercise mentioned in the above assignment.

Ethical Issue \#3: Accounting, recognized as the language of business, produces financial information that forms a sound basis for investors (among others) to base

decisions upon.

\section{BACKGROUND}

Textbook authors and scholars alike often define accounting as the language of business. Back in 1953, Avery wrote that if useful, "...[A]ccounting is the language of business and therefore provides the only common ground upon which sound decisions can be made" (p. 86). Textbook authors Horngren and Harrison, Jr. (2007) echo this descriptive phrase today saying indeed accounting is the language of business because it is "...the information system that measures business activity, processes the data into reports, and communicates results to decision makers" (p. 4).

We know that the reports mentioned in the Horngren and Harrison, Jr. quote above are primarily financial statements (for publicly traded firms anyway). The presentation of financial statement information is critical as the multitude of internal and external users of these statements depend upon this information to make decisions. Of primary concern is the investor user group who uses accounting information, summarized in the financial statements, as a decision-investment tool.

With the "language of business" status and the presentation of financial statements/reports that are relied upon by investors worldwide, it appears that accountants serve the needs of many people and provide a valuable service to society. But why again are investors (and others) so willing to base investment decisions (for example) upon the reported numbers in a company's financial statements? Because accounting produces reliable, relevant information? Does this imply, by default, that all business decisions are rooted in some aspect of accounting (be it in the published financial reports, a budget, or a cost-benefit analysis prepared by a management accountant)? What do you think our counterparts in management, economics, and theology would have to say about this notion?

While much is right about financial reporting, new challenges face the accounting profession and are sure to have an impact upon the future of the financial reporting process. As Rimerman (1990) reports, numerous factors have contributed to the changing perception of the relevance of financial statement information. He is not alone in the argument that the conceptual framework of accounting and the generally accepted accounting principles (GAAP) have failed to keep pace with the radically changing business environment of today (see also Kieso et al. 2007). For 
instance, Rimerman (1990) notes that the GAAP model does not include many nonmonetary assets like goodwill (internally generated), customer base, managerial skills, brand image, and other intangible assets. Despite their increased importance, today's financial reporting process fails to provide much information on these soft assets.

If accounting is the language of business ought it not be sophisticated enough to keep up with these changing times? How do we address the fact that nonfinancial information, which appears to also be key in investors' decision making processes, is not captured in the financial statements that are said to represent the true picture of a firm's financial health? Christian ethics maintains accountants who make any attempt to mislead users of financial statement data are guilty of placing a stumbling block before the blind, an action God warned against as stated in the Bible (Leviticus, 19:14). Additionally, "[i]nvestors and creditors rely on financial statements, and have a right to assume they are accurate" (Gellis, Giladi, and Friedman, 2002, p.12).

\section{THE TENSIONS OF THIS ARGUMENT}

While we expect that accounting is capable of capturing business transactions that are able to be quantified, there are aspects of business that do not lend themselves to being summed up in terms of "dollars and cents". For instance, we talk about assets in accounting and even human capital or human assets. But, we do not see the "value" of human capital reflected in a firm's balance sheet. Why not? It is often argued that quantifying the contributions of human capital in a firm actually devalues the worth of the person as an individual. Even the comprehensive "language of accounting" does not lend itself (nor may it be an appropriate means to do so) to the ability to capture what is not estimable in the first place: the value of a human being. Other intangible assets like goodwill, branding, and research and development are also not subject to the same accounting treatment as physical, plant assets. The standard setters have not ignored this fact of business life; they simply cannot reach a consensus regarding the proper way to measure and subsequently value these intangible assets. Without the ability to report upon these assets however, are accountants misrepresenting the true financial health of the firm and thereby misleading those who rely upon the financial information as a means for making financial decisions? Does the "language of business" imply that it is acceptable to ignore everything that we cannot accurately measure, even if it could be deemed relevant to investors (and others') decision making processes?

Biblically, the need for reliable, relevant information can be traced back to Moses' recordkeeping for contributions of metals used in the construction of the Holy Tent. All of the gold, silver, and bronze was weighed and verified. The accountability for each metal was also documented as the Levites were instructed by Moses to document the metals used in constructing the bases, altar, tools for the altar, and curtains (Exodus 38: 21-31). Moses' exercise in accurate recordkeeping was intensified by his decision to employ an independent third party in examination and documentation. While we have this biblical support, what can Scripture tell us about what ought and ought not be measured and reported in financial statement information? Certainly back in the days of Moses it could not have been "easy" to find a way to measure the use of the metals, but it was deemed an important process to undertake nonetheless. Today, where do we deem it permissible to draw a line between what is and what is not comprehensive accounting?

Are accountants faithful stewards of reliable, relevant information? If so, the idea of faithful stewardship includes accountability for the ways in which we manage the use of things that our master has entrusted us with (Chewning, 1999). In addition to the accounting for the contributions utilized in the building of the Tabernacle, in Matthew servants are given varying amounts of gold and the master then returned for the servants to account for how they used the gifts entrusted to them (Matthew 25:14-30). As Stevens (2005) points out, we are entrusted with the care of the world and are accountable to God. This trustee-relationship embraces, among other things, the care of creation and managing "the resources of the earth and sea" (p.232) and carries with it this theme of responsibility and accountability. As stewards, we are to take care of the earth (Genesis 2:15). It certainly does appear that as accountants, we have taken on the role of stewards of reliable, relevant information. We have a duty to manage the use of resources, even if the resource in question is information, and to be held accountable for the reliable, accurate, presentation of such information. Issued financial statements should "...clearly state all assumptions made, and be as honest and understandable as possible" (Gellis et al., 2002, p.12). 


\section{STUDENT ASSIGNMENT}

Read the article Accounting as a language (Avery, 1953) to gain a deeper understanding of the discussion surrounding the argument posed above that accounting is a comprehensive language of business that processes financial information into reports and communicates the findings to decision makers. Inherent in this assertion is the notion that the information presented is reliable and relevant, so much so that users of the information can base financial investment (or other) decisions upon the presented data. However, you are aware that there are liabilities on the balance sheet that are mere estimates (contingent liabilities for example) as well as items (assets) missing from the balance sheet that represent actual value to the reporting firm (i.e. internally generated goodwill, human capital, and brand awareness). To this end, are financial documents generated from the accounting process (i.e. financial statements) truly representative of a firm's financial condition? What other information, from management theory, a theological perspective, and/or a legal/economic perspective, might a user of such data need to consider?

In preparing for this assignment you should also review the text The Ethics of Management $\left(2006,5^{\text {th }}\right.$ edition) by LaRue Hosmer. Note that Hosmer suggests that the analytical process that leads to eventual resolution of business dilemmas often involves giving consideration to legal requirements, determining the economic outcomes, and evaluating the ethical duties of the parties involved. With these factors in mind, you should visit a faculty member in management, theology, or economics (you are welcome to meet with more than one if you so choose). You need to describe to them the premise of our discussion of the "language of business" and how accounting provides relevant, reliable information for users to base decisions upon. Then, ask the faculty member how they feel about this assessment of accounting. What do they say about the 'best' way to measure a firm's financial health? Or more specifically, how does their discipline area address the measurement of a firm's health in order to base investment decisions? What does the faculty member say about what informs their own personal feelings on this matter: Are they influenced primarily by standards/guidelines within their own discipline area, their educational background, their spiritual beliefs, their own moral compass, a combination of some set of these?

Be prepared to write up a formal paper on your interview/discussion. After giving your interviewees comments, respond to how you feel about the ability of accounting to represent a comprehensive language of business that communicates reliable, relevant information to users. How does your take on this matter compare and contrast with the view given to you by the interviewee? Have your own thoughts been influenced/changed based upon your discussion with the other party? How?

\section{TEACHING GUIDE}

This assignment could be given to students in the first Intermediate Accounting course.

The purpose of this assignment is to engage students in research about the value (or lack there of) of accounting information from perspectives other than those of accounting scholars. In the background, I mentioned that a tenant of this ethical statement is that accounting information is the basis upon which economic decisions for the firm and for investors can be made. What would those in management, theology, and economics have to say about this? Given the inherent limitations in our system of financial reporting, are we accurate in saying that the financial information that comes out of the accounting processes is reliable and relevant enough for users to base their decisions upon?

As our College is a liberal arts institution in the Catholic tradition, we emphasize the integration of all aspects of liberal education with the studies of the business curriculum. Therefore, I feel it would be in line with the institution's values to provide an assignment that would require students to think about accounting while relating that to theology and economics (along with management). It provides a unique opportunity for students to reflect on what they have learned in past business and non-business courses and relate it to their study of accounting. This is critical in many ways but especially in emphasizing the importance of appreciating differing perspectives on business and the need to integrate one's thoughts about business with principles from outside the business curriculum. 
Additional discussion after the completion of this assignment might work into the 'dangers' of professions and professionalism; in this case a level of superiority of one discipline over another. As Stevens and Banks (2005) point out, the autonomy of professional life all too often leads to smugness; too much pride of place and position. However, God warns even a king must "not consider himself better than his brothers" (Duet. 17:20). Stevens and Banks (2005) also emphasize that in the modern world we have secularized the concept of profession away from that of a holy calling to an occupation with special responsibilities and a special status. The authors raise a good question which is worthy of discussion during this lesson: As today's professionals claim a unique role that brings them self-fulfillment, are they doing so instead of professing to serve God? If so, is the statement made by George Bernard Shaw that every profession is a conspiracy against the laity, out of line or right on?

As students begin to discuss the viewpoints they were exposed to from their conversations with management, theology, and economics professors there might be some obvious tendency to imply that one viewpoint and/or profession is superior in some way to another in fulfilling the role of producing information for the public to base financial decisions upon. Hopefully this exercise will emphasize the need not just in business, but in life, for Christians to proclaim a worldview for professional life that is fully integrated. "The professional must be a person, a whole person" (Stevens and Banks, 2005, p.210). Just as that worldview ought to include moral education, character development, and technical career training, so too ought it to include the ability to integrate the perspectives of other disciplines and respect for their contributions.

\section{AUTHOR INFORMATION}

Dr. Amy L. Doolan, Mercyhurst University, Walker School of Business. E-mail: adoolan@mercyhurst.edu

\section{REFERENCES}

1. Arens, A., Elder, R., and Beasley, M. (2008). Auditing and assurance services, An integrated approach, $\left(12^{\text {th }}\right.$ ed.) Upper Saddle River, NJ: Pearson Education, Inc.

2. Association for the Advancement of Collegiate Business Schools (AACSB) Ethics Education Task Force (2004). Ethics Education in Business Schools, retrieved July 1, 2007 from http://www.aacsb.edu/resource centers/ethicsedu/EETF-report-6-25-04.pdf.

3. Avery, H. (1953). Accounting as a language. Accounting Review, 28(1), 83-87.

4. Bean, D. and Bernardi, R. (2006, July). Ethics in accounting education: The forgotten stakeholders. The CPA Journal, 56-57.

5. Bean, D. and Bernardi, R. (2007, January). Accounting ethics courses: Do they work? The CPA Journal, 64-67.

6. Beauchamp, T., and Bowie, N. (2001). Ethical theory and business $\left(6^{\text {th }}\right.$ ed). Upper Saddle River, NJ: Prentice Hall.

7. $\quad$ Chewning, R. (Ed.). (1989). Christians in the marketplace series Volume 2: Biblical principles \& economics, The foundations. Colorado Springs, CO: Navpress.

8. $\quad$ Clikeman, P. (2003). Educating for the Public Trust. CPA Journal, 73(8), 80.

9. $\quad$ Copeland, Jr., J. (2005). Ethics as an imperative. Accounting Horizons, (19), 1, 35-43.

10. Gellis, H., Giladi, K., and Friedman, H. (2002). Biblical and Talmudic basis of accounting ethics. The CPA Journal, (Sept.), 11-13.

11. Goldsmith, G. (2005). Teaching ethics in accounting in postmodern America, Abstract, Niagara Conference, 2005, Retrieved July 7, 2007 from http://www.niagara.edu/ciaer/2005/documents/161TeachingAccountingEthicsAbstractforNiagaraConferenc $\underline{\text { e.doc }}$

12. Horngren, C. and Harrison, Jr., W. (2007). Accounting, ( $7^{\text {th }}$ ed.) Upper Saddle River, NJ: Pearson Education, Inc.

13. Hosmer, L. (2006). The ethics of management (5 $5^{\text {th }}$ ed.). New York: McGraw-Hill.

14. Howard, J. (2007, April). Ethics cannot be taught. The CPA Journal, 15.

15. Kieso, D., Weygandt, J., and Warfield, T. (2007). Intermediate Accounting. Hoboken, NJ: John Wiley \& Sons, Inc. 
16. National Association of State Boards of Accountancy (NASBA, 2006). Exposure Draft: Additions and Modifications to Uniform Accountancy Act Model Rules, retrieved July 3, 2007 from http://www.nasba.org/862571B900737CED/PNL/UAARulesEDNov06/\$file/UAARulesEDNov06.pdf

17. Ricchiute, D. (2006). Auditing, $\left(8^{\text {th }}\right.$ ed.) Mason Ohio: Thomson South-Western Publishing.

18. Rimerman, T. (1990). The changing significance of financial statements. Journal of Accountancy, 79-83.

19. Rothenberg, E. (2003, October). Incorporating business ethics into introductory accounting courses. The CPA Journal, 6-8.

20. Stevens, R. and Banks, R. (Ed.). (2005). The marketplace ministry handbook. Vancouver, Canada: Regent College Publishing. 